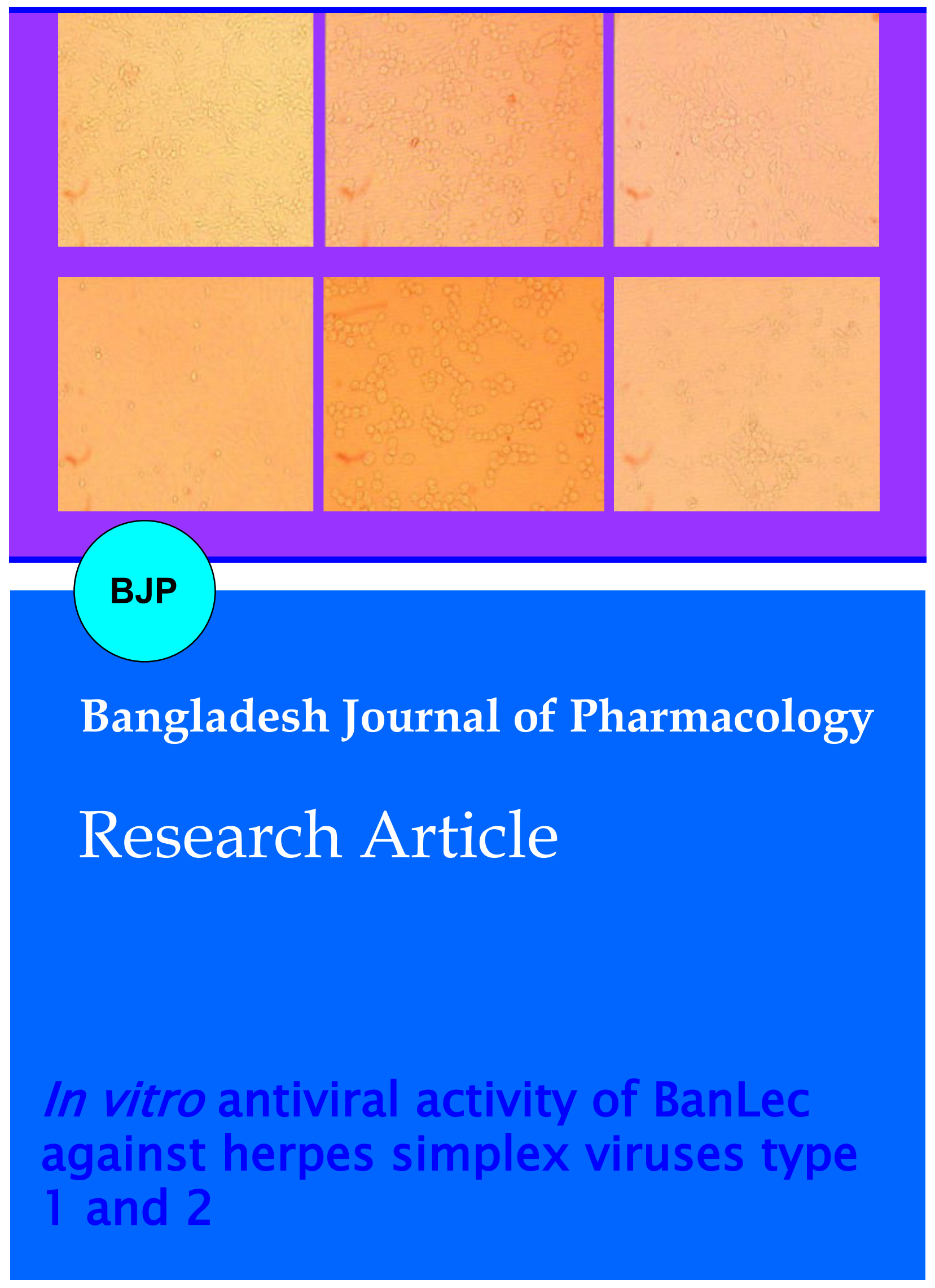




\title{
In vitro antiviral activity of BanLec against herpes simplex viruses type 1 and 2
}

\author{
Arisha Taj Mahaboob Batcha', Ashish Wadhwani² and Gowri Subramaniam ${ }^{3}$ \\ ${ }^{1}$ Department of Biochemistry, Dr. N. G. P. Arts and Science College, Coimbatore 641048, Tamil Nadu, India; \\ ${ }^{2}$ Department of Pharmaceutical Biotechnology, JSS Academy of Higher Education and Research, JSS College of \\ Pharmacy, Ooty 643001, Tamil Nadu, India; ${ }^{3}$ Department of Biochemistry, Dr. N. G. P. Arts and Science College, \\ Coimbatore 641048, Tamil Nadu, India.
}

\begin{tabular}{|lr}
\hline Article Info \\
\hline Received: & 21 July 2019 \\
Accepted: & 10 February 2020 \\
Available Online: & 8 March 2020 \\
DOI: 10.3329/bjp.v15i1.42320 & \\
& \\
& \\
Cite this article: & \\
Batcha ATM, Wadhwani A, Subrama- \\
niam G. In vitro antiviral activity of \\
BanLec against herpes simplex viruses \\
type 1 and 2. Bangladesh J Pharmacol. \\
2020; $15: 11-18$.
\end{tabular}

\section{Abstract}

The present study evaluates the antiviral activity of banana lectin (BanLec) against herpes simplex virus type 1 and 2 (HSV-1 and HSV-2). Lectin was isolated from the ripen pulp of bananas (Musa paradisiaca). The study showed that lectin exhibited hemagglutination activity towards human erythrocytes $\mathrm{A}, \mathrm{B}, \mathrm{AB}$ and $\mathrm{O}$ group. The molecular weight of BanLec using SDS gelelectrophoresis was found to be 14,000-30,000 Da. Cytotoxicity of BanLec on the Vero cell lines showed an inhibitory concentration of $172.7 \mu \mathrm{g} / \mathrm{mL}$. BanLec was virucidal and showed no cytotoxicity at the concentration tested. The lectin showed a dose-dependent antiviral activities, inhibiting HSV-1 by $16.0 \mu \mathrm{g} / \mathrm{mL}$ with selectivity index 10.8 and HSV-2 inhibition by $67.7 \mu \mathrm{g} / \mathrm{mL}$ with selectivity index 2.6. These results corroborate that BanLec could be a rich source of potential antiviral compound for HSV-1 when compared to HSV-2.

\section{Introduction}

Lectins are a unique and heterologous class of proteins with the ability to recognize and reversibly bind a variety of sugar structures present on the cell surface (Santos et al., 2014). They are found in a wide range of organisms, from viruses and bacteria to animals, plants, and humans (Mitchell et al., 2017). They have important biological functions in the organisms, including cell-cell interaction, protection from pathogens, cell adhesion, and intracellular translocation of glycoproteins, and they also act as storage proteins (Yamashita et al., 1999; Jiang et al., 2006; Wang et al., 2007). At present, they are being widely used in studies of biochemistry, cell biology, immunology, glycobiology and have widespread applications in biomedical researches (Sharon and Lis, 1989). Due to its fine specificity, most plant lectins have been employed for various applications including cancer therapy and virus research.
Banana lectin (BanLec) was first isolated from Musa paradisiaca (Koshte et al., 1990). It is a homodimeric protein that binds mannose and mannose-containing oligosaccharides and functions as a potent T-cell mitogen (Meagher et al., 2005; Koshte et al., 1992).

Herpes simplex virus (HSV) is a DNA-containing enveloped virus, which brings commonly viral infections in humans causing a variety of diseases. HSV-1 and HSV2 can be distinguished based on clinical manifestations, biochemical and serological characteristics. However, in patients with an immature or weak immune system, such infections can be serious and even life-threatening (Naesens and De Clercq 2001; Whitley and Roizman 2001). The current investigation was undertaken to test the BanLec for their antiviral activity against HSV-1 and HSV-2. The lectin was found to possess various in vitro activity towards HSV strains and potent anti-viral response against HSV-1 at low concentration far below the cytotoxicity threshold. 


\section{Materials and Methods \\ Collection of plant material}

Ripe banana fruits were purchased from the local market. It was kept for 2 days at room temperature allowing it to be slightly over ripen. The ripened banana pulp was washed thoroughly using tap water and wiped using a clean cloth. The succulent parts of the banana pulp were cut into pieces.

\section{Isolation and purification of lectin}

The pulps of the bananas were blended in distilled water using a warning blender. To the supernatant obtained after centrifugation (15000 x g, $30 \mathrm{~min})$ of the homogenate, ammonium sulfate was added to achieve $10 \%$ saturation. The mixture was centrifuged again (15000 x g, $30 \mathrm{~min}$ ) and ammonium sulfate was added to attain $80 \%$ saturation. The supernatant obtained after centrifugation was then dialyzed against distilled water at $4^{\circ} \mathrm{C}$ to get rid of ammonium sulfate. Tris- $\mathrm{HCl}$ buffer ( $\mathrm{pH}$ 7.8) was added to the dialyzed supernatant until the concentration of Tris attained $10 \mathrm{mM}$. The supernatant was then loaded on a $3 \times 10 \mathrm{~cm}$ column of DEAEcellulose (Sigma) in $10 \mathrm{mM}$ Tris- $\mathrm{HCl}$ buffer $(\mathrm{pH} 7.8)$. After removal of the unadsorbed fraction (D1), adsorbed fractions (D2 and D3) were eluted with starting buffer containing 0.2 and $1 \mathrm{M} \mathrm{NaCl}$, respectively. After examination of the hemagglutinating effect of fractions, the active fraction causing hemagglutination was collected and tested for antiviral activity (Cheung et al., 2009).

\section{Lectin concentration}

The lectin content of the samples obtained during the purification process was determined by the method of (Lowry et al., 1951) using bovine serum albumin as the

\section{Box 1: Hemagglutination Test}

\section{Principle}

A method for titering viruses based on their ability to attach to molecules present on the surface of red blood cells. The hemagglutination titer is a simple number of the highest dilution factor that produced a positive reading.

\section{Requirements}

BanLec; Centrifuge machine; Biological safety cabinet; Conical tubes (15 mL); Disposable pipettes (1, 5, and $10 \mathrm{~mL})$; Human erythrocyte; Inverted microscope; 96-well round-bottom microtiter plate; Micropipette; Phosphate buffer solution; Sterile disposable aerosol resistant tips $(160 \mu \mathrm{L})$

\section{Procedure}

Step 1: Phosphate buffer solution $(50 \mu \mathrm{L})$ was added to each well

Step 2: Banana lectin $(50 \mu \mathrm{L})$ was added in the first column

Step 3: Mix each well and transfer $50 \mu \mathrm{L}$ to the next well on its standard. Readings at $280 \mathrm{~nm}$ were also used to determine the protein content of the column eluates.

Molecular weight determination by sodium dodecyl

Sodium dodecyl sulfate-polyacrylamide gel electrophoresis (SDS-PAGE) was carried out following the procedure of Laemmli, 1970 using a 10\% resolving gel and a 5\% stacking gel. At the end of electrophoresis, the gel was stained with Coomassie brilliant blue. After destaining, the electrophoretic mobilities of the marker proteins and the purified lectin were determined.

\section{Virus and virus titration}

For the anti-HSV-1 and HSV-2 activity screening, African green monkey kidney cells (Vero) were grown in minimum essential medium supplemented with $10 \%$ Fetal bovine serum, penicillin $(100 \mathrm{U} / \mathrm{mL})$, streptomycin $(100 \mu \mathrm{g} / \mathrm{mL})$ and amphotericin B $(25 \mu \mathrm{g} / \mathrm{mL})$. Cell cultures were maintained at $37^{\circ} \mathrm{C}$ in a humidified $5 \% \mathrm{CO}_{2}$. HSV-1 and HSV-2 strain were propagated in Vero cells. The virus was divided into aliquots and stored at $-80^{\circ} \mathrm{C}$ until use. Virus titers were calculated as $50 \%$ tissue culture infectious dose $\left(\right.$ TCID $_{50}$ ) by cytopathic effect assay. HSV-1 and HSV-2 titers were obtained by the limit-dilution method and expressed atmosphere as 50\% tissue culture infectious dose per $\mathrm{mL}\left(\mathrm{TCID}_{50} / \mathrm{mL}\right.$ ) (Reed and Muench, 1938).

\section{Determination of mitochondrial synthesis by MTT assay}

Cytotoxicity of BanLec was assessed by MTT ((3-[4,5-16 dimethylthiazol-2-yl]-2,5-diphenyltetrazolium bromide) assay using Vero cells in 96-well plates according to the methodology proposed (Francis and Rita, 1986). The percentage of cell viability was calculated and the

right. Repeat mixing and transferring $50 \mu \mathrm{L}$ down the length of the plate. Discard $50 \mu \mathrm{L}$ from the last well into a bleach solution

Step 4: Add $50 \mu \mathrm{L}$ of $0.5 \%$ red blood cell working solution to each well. Mix gently

Step 5: Leave at room temperature for 30-60 min to develop. Negative results appeared as dots in the center of roundbottomed plates. Positive results formed an uniform reddish color across the well

Step 6: The hemagglutination titer was a simple number of the highest dilution factor that produced a positive reading

Note

A round-bottomed 96-well dish is preferred. Flat-bottomed plates will also work, but need to be placed at an incline to develop

References (video)

Babu et al., 2016 
concentration of drug or test samples needed to inhibit cell growth by $50 \%$ values were generated from the dose-response curves for each line.

\section{In vitro antiviral activity by MTT assay}

A rapid and sensitive procedure to evaluate antiviral compounds in vitro is based on spectrophotometrical assessment for the viability of virus-infected and mockinfected cells via in situ reductions of a tetrazolium dye by MTT as per the method described (Kurokawa et al., 2016).

\section{Data analysis}

The 50\% inhibitory concentration $\left(\mathrm{IC}_{50}\right)$ and 50\% effective $\left(\mathrm{EC}_{50}\right)$ concentrations were calculated from concentration-effect curves after linear regression analysis. The results represent the mean \pm standard error of the mean values of three different experiments.

\section{Results}

\section{Purification of BanLec from M. Paradisiaca}

Four peaks of protein were detected using this step of purification, as shown (Figure 1A). Hemagglutination activity (HA) was found only in the third peak. Maximum activity was detected at fraction number 8 with total lectin content of $78 \mathrm{mg} / \mathrm{mL}$. The fraction that gave the highest agglutination activity, peak (3) lectin was taken for the entire study.

\section{Determination of molecular weight by SDS-PAGE}

Multiple bands could be seen in the BanLec when comparing with the marker. Examining the SDS-PAGE result, the lectin sample showed a concentrated band at the low molecular weight. However, the lectin sample had a band at around 14-30 kDa (Figure 1B).

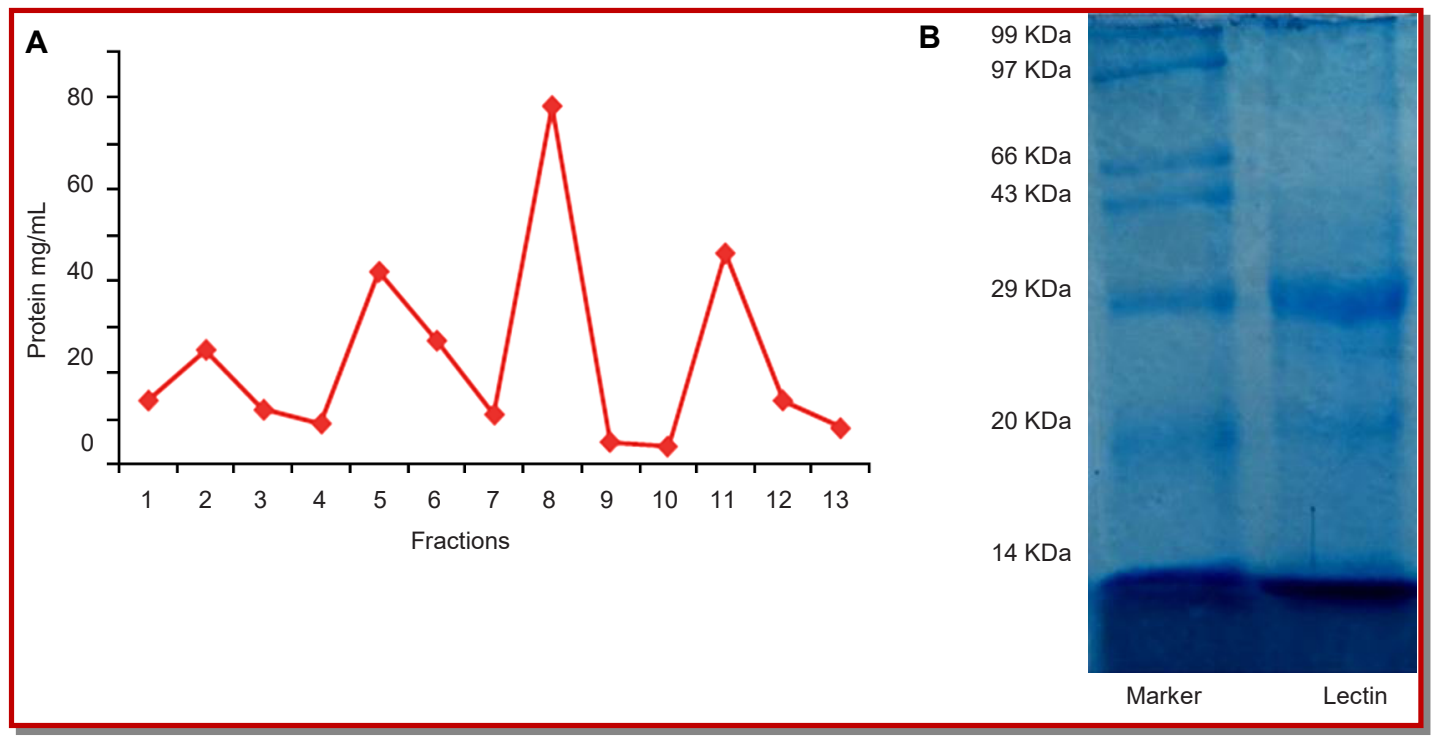

Figure 1: Elution profile of BanLec purification, with $80 \%$ ammonium sulfate precipitate on DEAE cellulose column (A); SDSPAGE representing the molecular weight of BanLec (B). Left lane contained marker proteins and the right lane contained $10 \mu \mathrm{g}$ of BanLec

\begin{tabular}{|c|c|c|c|c|c|c|c|c|c|c|c|}
\hline \multicolumn{12}{|c|}{ Table I } \\
\hline \multicolumn{12}{|c|}{ Calculation of hemagglutination activity of DEAE cellulose purified BanLec } \\
\hline Dilution & $1: 1$ & $1: 2$ & $1: 4$ & $1: 8$ & $1: 16$ & $1: 32$ & $1: 64$ & $1: 128$ & $1: 256$ & $1: 512$ & 1:1024 \\
\hline $\begin{array}{l}\text { Lectin concentration } \\
\qquad(\mu \mathrm{g} / \mathrm{mL})\end{array}$ & 100 & 50 & 25 & 12.5 & 6.25 & 3.125 & 1.56 & 0.78 & 0.39 & 0.19 & 0.09 \\
\hline A & + & + & + & + & + & + & + & + & + & - & - \\
\hline B & + & + & + & + & + & + & + & + & + & - & - \\
\hline $\mathrm{AB}$ & + & + & + & + & + & + & + & + & - & - & - \\
\hline $\mathrm{O}$ & + & + & + & + & + & + & + & - & - & - & - \\
\hline
\end{tabular}




\begin{tabular}{|c|c|c|c|c|c|c|}
\hline \multicolumn{7}{|c|}{ Table II } \\
\hline \multicolumn{7}{|c|}{ Summary of the purification steps of the BanLec } \\
\hline Purification stages & $\begin{array}{l}\text { Protein } \\
(\mathrm{mg} / \mathrm{mL})\end{array}$ & $\begin{array}{l}\text { Protein yield } \\
\text { (mg) }\end{array}$ & Blood Groups & $\mathrm{HA}(\text { titre })^{*}$ & $\begin{array}{c}\text { Specific activity } \\
(\mathrm{HU} / \mathrm{mg})\end{array}$ & $\begin{array}{c}\text { Purification } \\
\text { fold }\end{array}$ \\
\hline \multirow[t]{4}{*}{ Crude extract (100 mL) } & \multirow[t]{4}{*}{0.83} & \multirow[t]{4}{*}{83} & A & 6,400 & 77.1 & - \\
\hline & & & B & 3,200 & 36.0 & - \\
\hline & & & $A B$ & 1,600 & 19.3 & - \\
\hline & & & O & 1,600 & 19.3 & - \\
\hline \multirow[t]{4}{*}{ Ammonium sulfate $(50 \mathrm{~mL})$} & \multirow[t]{4}{*}{0.74} & \multirow[t]{4}{*}{74} & A & 12,800 & 173 & 2.2 \\
\hline & & & B & 6,400 & 86.5 & 2.4 \\
\hline & & & $A B$ & 1,600 & 22.0 & 1.1 \\
\hline & & & $\mathrm{O}$ & 1,600 & 22.0 & 1.1 \\
\hline \multirow[t]{4}{*}{ DEAE cellulose column (50 mL) } & \multirow[t]{4}{*}{0.78} & \multirow[t]{4}{*}{78} & A & 25,600 & 328.2 & 4.3 \\
\hline & & & B & 25,600 & 328.2 & 4.3 \\
\hline & & & $A B$ & 12,800 & 164.1 & 8.5 \\
\hline & & & 0 & 6,400 & 82.05 & 4.3 \\
\hline
\end{tabular}

\section{Hemagglutination activity}

BanLec had the ability to hemagglutinate human red blood cell types A, B, AB and O (Table I). The ability of the sample to hemagglutinate was determined by its ability to suspend red blood cells in a buffer, done through their ability to bind to two red blood cells and to form a lectin-erythrocyte-lectin matrix, leading to their clumping. When agglutination occurs, crosslinked red blood cells form a network that prevents the red blood cells from sedimenting to the bottom of the well. They appear like a carpet that covers the whole microtiter plate well. When there was no agglutination, the red blood cells sedimented and formed a button on the bottom of the well.

The isolated fraction showed the agglutination activity for various human erythrocyte suspensions namely (A, $\mathrm{B}, \mathrm{AB}$ and $\mathrm{O}$ ) at 328.2, 328.2, 164.1, 82.1 HU/mg for BanLec respectively. The least concentration of lectin causes visible agglutination in blood cells $\mathrm{A}$ and $\mathrm{B}$ are $0.4 \mu \mathrm{g} / \mathrm{mL}$ followed by the least concentration of agglutination in group $\mathrm{AB}$ and $\mathrm{O}$ are $0.8 \mu \mathrm{g} / \mathrm{mL}$ and 1.6 $\mu \mathrm{g} / \mathrm{mL}$ respectively.

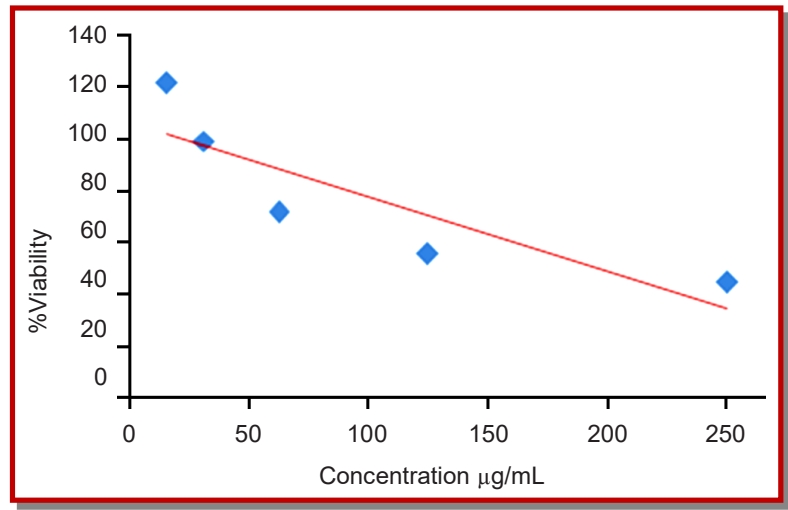

Figure 2: Concentration effect of BanLec on Vero cells. The $\mathrm{IC}_{50}$ was calculated using regression line. Data's were expressed as mean \pm SD from three independent experiments
The maximum concentration (lowest dilution) where there is agglutination that disappears, if further dilution happens is the specified titer that will be used in the purification process. This is 1:256 for both groups $A$ and B, 1:128 and 1:64 for groups AB and O. Here, PC acts as a positive control where all the wells agglutinated and $\mathrm{NC}$ as negative control were all the red blood cells have sedimented to the bottom of wells and formed a small button. Hemagglutinating activity of BanLec was stable at $0-80^{\circ} \mathrm{C}$ for $30 \mathrm{~min}$, but was abolished after exposure to $90^{\circ} \mathrm{C}$ for $30 \mathrm{~min}$. The hemagglutinating activity was stable over the $\mathrm{pH}$ range of 1-13. Although the agglutination assay was used qualitatively to provide evidence for the presence of lectin in isolated fractions, the results from multiple tests were combined to produce an arithmetic average of the highest dilutions that produced agglutination. The highest dilution that was positive for agglutination and the minimum concentration of the extract that produced agglutination (HU) for the different blood cells has been summarized in the (Table II).

\section{Cytotoxicity of BanLec by determination of mitochon- drial synthesis by MTT assay}

For the purified lectin, the number of viable cells decreased with increasing concentration of the lectin in a dose-responsive manner (Figure 2). The highest concentration of BanLec significantly decreases the number of viable cells relative to the control. No significant cytotoxicity was detected for BanLec at concentrations up to $250 \mu \mathrm{g} / \mathrm{mL}$ in cultured Vero cells. Therefore, it can be concluded that the $\mathrm{IC}_{50}$ (the concentration which causes $50 \%$ cytotoxic effect) was more than $100 \mu \mathrm{g} / \mathrm{mL}$ and a $50 \%$ inhibitory concentration $\left(\mathrm{IC}_{50}\right)>172.7 \mu \mathrm{g} / \mathrm{mL}$ was obtained. Hence from this conclusion, the antiviral assays were performed at a concentration below or equal to $100 \mu \mathrm{g} / \mathrm{mL}$. IC 50 values obtained by microscopic evaluation of cell morphology was significantly different from $\mathrm{EC}_{50}$ values obtained by 

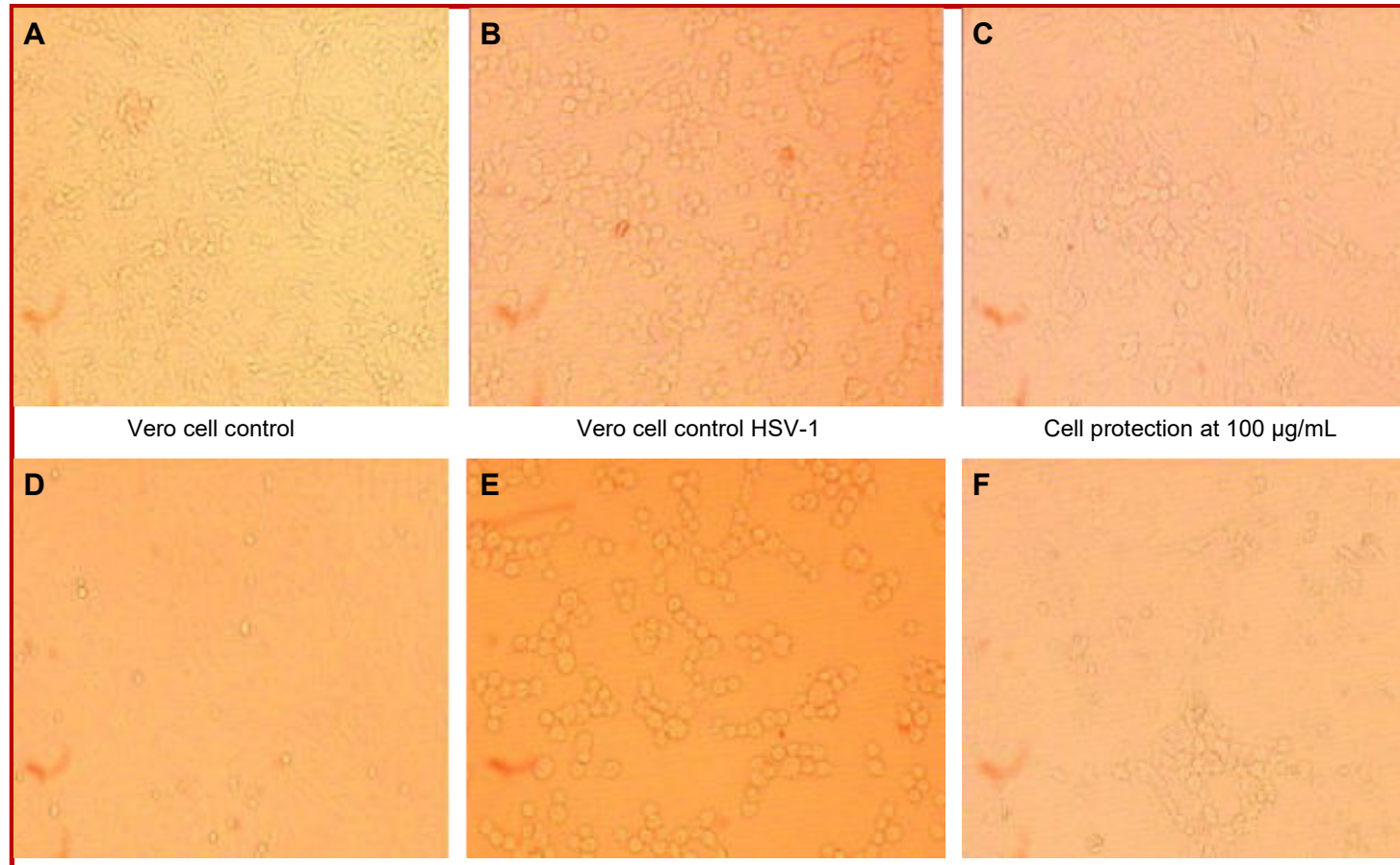

Vero cell control

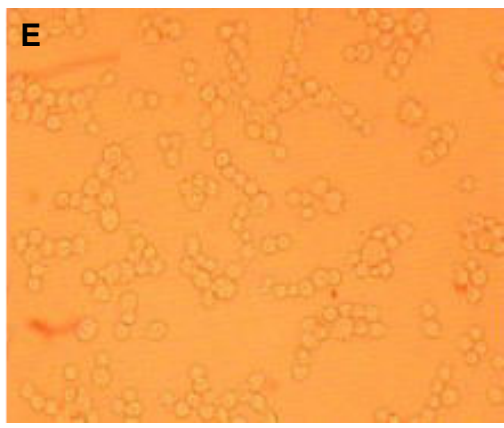

Vero cell control HSV-2

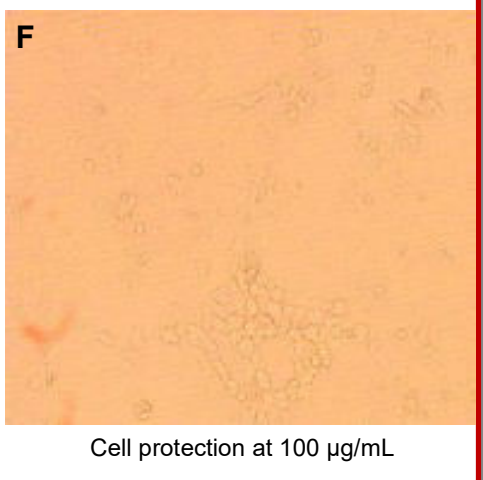

Figure 3: Antiviral activity of BanLec against HSV-I (A-C) and HSV-2 (D-F) and its morphological changes in the Vero cells were examined under a phase contrast microscopy

the MTT assay. Cells appeared almost normal when observed microscopically.

\section{Effects of BanLec on HSV-1 in vitro}

The result indicated the TCID 50 of HSV-1 was different in all groups treated with various concentrations of lectin $(12.5,25,50,100 \mu \mathrm{g} / \mathrm{mL})$ and showed a cytopathic effect on HSV-I. The assessment of the viability was depending on the morphological changes and condensation of insoluble formazan particles as shown in (Figure 3). Firstly, cultured Vero cells were treated with $100 \mu \mathrm{g} / \mathrm{mL}$ of BanLec. After 48 hours, the MTT assay was applied for the assessment of any toxic effect on cell viability. This pre-step was done for the optimization of BanLec. Therefore, all subsequent studies were done for BanLec at concentrations of $\leq 100$ $\mu \mathrm{g} / \mathrm{mL}$.

HSV-1 infected Vero cells that were treated with 12.5 $\mu \mathrm{g} / \mathrm{mL}$ of lectin showed inhibition percentage of about $77.4 \%$ with cell protection of $22.7 \%$ of virus growth. The activity was elevated subsequently. Therefore, lectin exhibits protective activity against the HSV-1. Results shown in (Figure 4) revealed the lectin effects. HSV-1 growth and its expression to its protective activity on Vero cells by $66.3 \%$ of cell protection and inhibition of $33.7 \%$ of virus growth at $25 \mu \mathrm{g} / \mathrm{mL}$ concentration were observed. This inhibition percentage decreased gradually with subsequent increase in BanLec concentration to reach $27.2 \%$ and $16.1 \%$ in inhibition percentage with cell protection of $72.8 \%$ and $83.9 \%$ at $50 \mu \mathrm{g} / \mathrm{mL}$ and 100 $\mu \mathrm{g} / \mathrm{mL}$ respectively.

By evaluating the cell protection from $10 \mathrm{TCID}_{50}$, the higher antiviral activity of BanLec was shown at a higher concentration of $100 \mu \mathrm{g} / \mathrm{mL}$ with $83.9 \%$ cell protection in virus growth with inhibition of $16.1 \%$. From the data obtained from MTT assay for antiviral action of BanLec against the HSV-1 strain, the dose that inhibited viral infection by $50 \%\left(\mathrm{EC}_{50}\right)$, the effective concentration required to inhibit $50 \%$ virus infection with 12.5, 25, 50, and $100 \mu \mathrm{g} / \mathrm{mL}$ of lectin was determined by plotting the graph against the inhibition of the virus yield versus the concentration of lectin by GravPad Prism (Figure 4).

From the graph, the $\mathrm{EC}_{50}$ and $\mathrm{IC}_{50}$ values of BanLec on HSV-1 were $16.0 \pm 2.5$ and $172.7 \mu \mathrm{g} / \mathrm{mL}$ respectively, and from the results obtained there was a significant difference between the values. Thus, BanLec has antiHSV-1 activity in vitro (Table III).

\section{Effects of BanLec on HSV-2 in vitro}

When cells were infected with HSV-2, the cells were killed by its cytotoxic effect. By the addition of increasing concentrations of BanLec, the viability of cells decreases. The antiviral effects of the drug of various concentrations against $10 \mathrm{TCID}_{50}$ titer of HSV-2 were compared morphologically and biochemically with those of the control group, they were found to inhibit viral reproduction. Cytopathic changes indicative of viral proliferation were found morphologically 


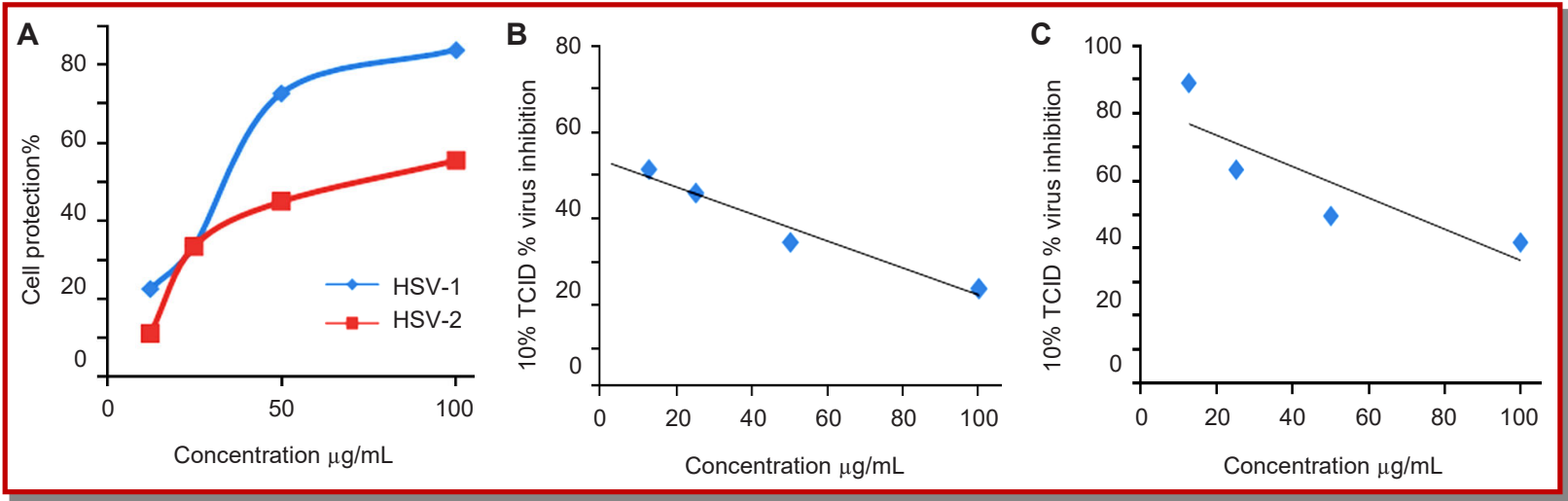

Figure 4: MTT antiviral assay on BanLec and the cell protection against HSV-1 and HSV-2 (A). Antiviral activity of BanLec against HSV-1 (B) and HSV-2 (C) virus at 10 TCID 50 (50\% Tissue culture infectivity dose). The EC 50 was calculated using regression line. Data's were expressed as mean \pm SD from three independent experiments

(Figure 3). All four concentrations of BanLec revealed varying degrees of inhibitory effect against the HSV-2 with various cell protection. In the cytopathic effect inhibition assay, the BanLec showed less protection against the HSV-2 virus challenge dose of $10 \mathrm{TCID}_{50}$.

According to MTT assay, the inhibition percentage gradually decreases with an increase in the concentration of BanLec to reach $55.6 \%, 45.1 \%, 33.6 \%$ and $11.2 \%$ of cell protection of virus growth (Figure 4). As for antiviral assay, $44.4 \%$ and $55.0 \%$ inhibition were observed when the concentration of BanLec was at 100 $\mu \mathrm{g} / \mathrm{mL}$ and $50 \mu \mathrm{g} / \mathrm{mL}$ respectively for $\mathrm{HSV}-2$ and $66.5 \%$ and $88.9 \%$ inhibition was observed at $25 \mu \mathrm{g} / \mathrm{mL}$ and $12.5 \mu \mathrm{g} / \mathrm{mL}$. The $50 \%$ effective concentration $\left(E_{50}\right)$ obtained was comparatively low as $67.7 \pm 2.4$ with inhibitory concentration $\mathrm{IC}_{50}$ of $172.7 \mu \mathrm{g} / \mathrm{mL}$ (Figure 4). The selectivity index (SI), calculated from the ratio $\mathrm{IC}_{50} / \mathrm{EC}_{50}$ was $2.6 \mu \mathrm{g} / \mathrm{mL}$ suggesting moderate to no activity of lectin on HSV- 2 (Table III).

\section{Table III}

\begin{tabular}{lr}
$\begin{array}{l}\text { Anti-HSV activity of BanLec by cytopathic inhibi- } \\
\text { tion assay }\end{array}$ & Concentration \\
\hline & \\
\hline Anti-HSV1 activity & $172.7 \mu \mathrm{g} / \mathrm{mL}$ \\
IC $_{50}$ & $16.0 \pm 2.5 \mu \mathrm{g} / \mathrm{mL}$ \\
EC $_{50}$ & 10.8 \\
Selectivity index & \\
Anti-HSV 2 activity & $172.7 \mu \mathrm{g} / \mathrm{mL}$ \\
IC $_{50}$ & $67.7 \pm 2.4 \mu \mathrm{g} / \mathrm{mL}$ \\
EC & 2.55 \\
Selectivity index &
\end{tabular}

IC 50 means $50 \%$ inhibition concentration, defined as a drug concentration that induced $50 \%$ inhibition of cultured Vero cells; $\mathrm{EC}_{50}$ means concentration that inhibits $50 \%$ cytopathogenic effect, as compared to the untreated culture; Selectivity index is the ratio of $\mathrm{IC}_{50}$ to $\mathrm{EC}_{50}$

\section{Discussion}

From the current findings, the BanLec inhibits the HSV replication of virus infected cells by evaluating the cytopathogenic effect. No significant cytotoxicity was detected for BanLec at concentration up to $250 \mu \mathrm{g} / \mathrm{mL}$. Further, using phase contrast microscopy cellular morphology was investigated in order to identify the effect of BanLec on Vero cells and it was found that the cells appeared almost normal. The results of MTT assay suggest that BanLec has association with antiviral activity and protective rule against HSV-1 infections.

Carbohydrate-binding agents such as lectins are prime candidate drugs for preventing sexually-transmitted viral infections (i.e. HIV, HBV, HCV, Herpes viruses), its oral bioavailability of such drugs is not required, and it can be an advantage to have poor absorption through cell layers in order to avoid some undesired systemic side effects (Balzarini, 2007). The mechanism of the antiviral activity of carbohydrate-binding proteins has recently been proposed as the interruption of virus fusion with its target cell and it can be mediated either by direct binding to the glycans moiety present on the virus envelope, similar to that of virus/ cell-cell interaction and hence preventing further interaction with the co-receptors (Balzarini, 2006). According to (Swanson et al., 2010) it has been reported that BanLec-1 could bind with human immunodeficiency virus (HIV) coat protein gp120 and prevent HIV infection. Previous studies showed that the lectins from different resources could interact with the coat or envelope proteins of different viruses. (Jin et al., 2004; Sun et al., 2003, Takebe et al., 2013). Lectin of the Galanthus nivalis agglutinin (GNA)-related lectin family it exhibit significant anti-human immunodeficiency virus (HIV) and anti-herpes simplex virus (HSV) properties that are closely related to their carbohydratebinding activities (Yang et al., 2011; Ding et al., 2010). Many plant lectins such as Canavalia ensiformis agglutinin, Concanavalin A (Okada and Kim, 1972), Soybean 
agglutinin, Wisteria floribunda agglutinin, Narcissus pseudonarcissus agglutinin, Bauhinia purpurea agglutinin and Eranthishyemalis agglutinin (Marchetti et al., 1995) possess inhibitory activity towards the infection by Herpes simplex virus. A mannose binding lectin from Typhonium divaricatum (L) Decne (family Araceae) displays antiviral effects against HSV-II (Luo et al., 2007) and similar effect on Jackfruit lectin (JFL) from Artocarpus heterophyllus (Wetprasit et al., 2000).

Virus replication is often detected by the morphological changes, or cytopathic effects that are seen in infected cell cultures. In the present investigation, the cytopathic effect of BanLec was dose-dependent with the most effective antiviral concentrations assumed to be from $12.5 \mu \mathrm{g} / \mathrm{mL}$ to $<100 \mu \mathrm{g} / \mathrm{mL}$. The higher antiviral activity of BanLec was shown at higher concentration 100 $\mu \mathrm{g} / \mathrm{mL}$. As the BanLec concentration increased there was a gradual decrease in the inhibition percentage resulting in increase in the cell protection. The cytopathic effect of BanLec on HSV-1 and HSV-2 treated Vero cells characterized by morphological changes like ballooning of the infected cells or their nuclei when compared to the Vero cell control. To confirm the antiviral potential of the BanLec, the (Selectivity Index) SI was calculated. A high selectivity index suggests that the BanLec would have good antiviral properties. In this study BanLec had high (selectivity index) SI of 10.8 with an effective concentration $\left(E_{50}\right) 16.0 \mu \mathrm{g} / \mathrm{mL}$ against HSV-1 showing good antiviral activity and had a least selectivity index (SI) 2.6 with an (EC50) $67.7 \mu \mathrm{g} /$ $\mathrm{mL}$ towards HSV-2 showing a very less antiviral activity towards the BanLec. Based on these results, BanLec is most appropriate to be developed into therapeutic compound for viral diseases.

\section{Conclusion}

BanLec displays inhibitory activity against HSV-1 but less potent towards HSV-2.

\section{Conflict of Interest}

The authors declare no conflict of interest to this study.

\section{Acknowledgements}

The authors wish to acknowledge the Department of Biochemistry, DST- FIST lab of Dr. N. G. P. Arts and Science College and Department of Pharmaceutical Biotechnology, JSS College of Pharmacy. Communication No: DrNGPASC 201920BS006.

\section{References}

Babu RJ, Kumar SN, Bidur C, Dharma K, Bijaya S, Rishika T.
Extraction of banana lectin from locally available banana in Nepali market using different $\mathrm{pH}$ solvents. Asian J Biochem Pharma Res. 2016; 2016.

Balzarini J. Antiviral chemistry. Chemother. 2007; 18: 1-11.

Balzarini J. Inhibition of HIV entry by carbohydrate-binding proteins. Antiviral Res. 2006; 71: 237-47.

Cheung $\mathrm{AH}$, Wong JH, Ng TB. Musa acuminate (Del Monte banana) lectin is a fructose-binding lectin with cytokineinducing activity. Phytomedicine 2009; 16: 594-600.

Ding J, Bao J, Zhu D, Zhang Y, Wang DC. Crystal structures of a novel anti-HIV mannose-binding lectin from Polygonatum cyrtonema Hua with unique ligand-binding property and superstructure. J Struct Biol. 2010; 171: 309-17.

Francis D, Rita L. Rapid colorimetric assay for cell growth and survival: Modifications to the tetrazolium dye procedure giving improved sensitivity and reliability. J Immunol Methods. 1986; 89: 271-77.

Jiang JF, Han Y, Xing LJ, Xu YY, Xu ZH, Chong K. Cloning and expression of a novel cDNA encoding a mannose specific jacalin-related lectin from Oryza sativa. Toxicon. 2006; 47:133-139.

Jin ZQ, Zhang DY, Xu BY. Cloning and developmental and tissue-specific expression of banana (Musa acuminate AAA) lectin gene. Yi Chuan Xue Bao. 2004; 31: 508-12.

Koshte VL, Aalbers M, Calkhoven PG, Aalberse RC. The potent IgG4-inducing antigen in banana is a mannosebinding lectin, BanLec-I. Int. Arch. Allergy Immunol. 1992; 97: 17-24.

Koshte VL, Van Dijk W, Van der Stelt ME, Aalberse RC. Isolation and characterization of BanLec-I, a mannosidebinding lectin from Musa paradisiaca (banana). Biochem J. 1990; 272: 721-26.

Laemmli UK. Cleavage of structural proteins during the assembly of the head of bacteriophage T4. Nature1970; 227: 680-85.

Lowry $\mathrm{OH}$, Rosebrough NJ, Farr AL, Randall RJ. Protein measurement with the Folin phenol reagent. J Biol Chem. 1951; 193: 265-75.

Luo Y, Xu X, Liu J, Li J, Sun Y, Liu Z, Liu J, Damme EV, Balzarini J, Bao J. A novel mannose-binding tuber lectin from Typhonium divaricatum (L.) Decne (family Araceae) with antiviral activity against HSV-II and anti-proliferative effect on human cancer cell lines. BMB Reports. 2007; 40: 358 $-67$.

Marchetti M, Mastromarino P, Rieti S, Seganti L, Orsi N. Inhibition of herpes simplex, rabies and rubella viruses by lectins with different specificities. Res Virol. 1995; 146: 21115.

Kurokawa M, Wadhwani A, Kai H, Hidaka M, Yoshida H, Sugita C, Watanabe W, Matsuno K, Hagiwara A. Activation of cellular immunity in herpes simplex virus type 1-infected mice by the oral administration of aqueous extract of Moringa oleifera Lam. leaves. Phytother Res. 2016; 30: 797804.

Meagher JL, Winter HC, Ezell P, Goldstein IJ, Stuckey JA. Crystal structure of banana lectin reveals a novel second 
sugar binding site. Glycobiology 2005; 15: 1033-42.

Mitchell CA, Ramessar K, O'Keefe BR. Antiviral lectins: Selective inhibitors of viral entry. Antiviral Res. 2017; 142: 37-54.

Naesens L, De Clercq E. Recent developments in herpes virus therapy. Herpes 2001; 8: 12-16.

Okada Y, Kim J. Incubation of concanavalin A with enveloped viruses and host cells. Virology 1972; 50: 507-15.

Reed LJ, Muench H. A simple method of estimating fifty percent endpoints. Am J Hyg. 1938; 27: 493-97.

Santos AFS, Da Silva MDC, Napoleao TH, Paiva PMG, Correia MTS, Coelho LCBB. Lectins: Function, structure, biological properties and potential applications. Curr Topics Pept Protein Res. 2014; 15: 41-62.

Sharon N, Lis H. Lectins as cell recognition molecules. Science 1989; 246: 227-34.

Sun H, Zhao CG, Tong X, Qi YP. A Lectin with mycelia differentiation and antiphytovirus activities from the edible mushroom Agrocybe aegerita. Biochem Mol Biol. 2003; 36: 214 -22 .

Swanson MD, Winter HC, Goldstein IJ, Markovitz DM. A lectin isolated from bananas is a potent inhibitor of HIV replication. J Biol Chem. 2010; 285: 8646-55.

Takebe Y, Saucedo CJ, Lund G, Uenishi R, Hase S, Tsuchiura T, Kneteman N, Ramessar K, Tyrrell DL, Shirakura M, Wakita $\mathrm{T}$, McMahon JB, O'Keefe BR. Antiviral lectins from red and blue-green algae show potent in vitro and in vivo activity against hepatitis C virus. PLoS One. 2013; 2013.

Wang H, Song L, C. Li, Zhao J, Zhang H, Ni D, Xu W. Cloning and characterization of a novel C-type lectin from Zhikong scallop Chlamysfarreri. Mol Immunol. 2007; 44 : 722-31.

Wetprasit N, Threesangsri W, Klamklai N, Chulavatnatol M. Jackfruit lectin: Properties of mitogenicity and the inhibition of herpes virus infection. Jap J Infect Dis. 2000; 53: 156-61.

Whitley RJ, Roizman B. Herpes simplex virus infections. Lancet 2001; 357: 1513-18.

Yamashita K, Hara-Kuge S, Ohkura T. Intracellular lectins associated with N-linked glycoprotein traffic. Biochimica Biophysica Acta. 1999; 1473: 147-60.

Yang Y, Xu HL, Zhang ZT, Liu JJ, Li WW, Ming H, Bao JK. Characterization, molecular cloning, and in silico analysis of a novel mannose-binding lectin from Polygonatum odoratum (Mill.) with anti-HSV-II and apoptosis-inducing activities. Phytomedicine 2011; 18: 748-55.

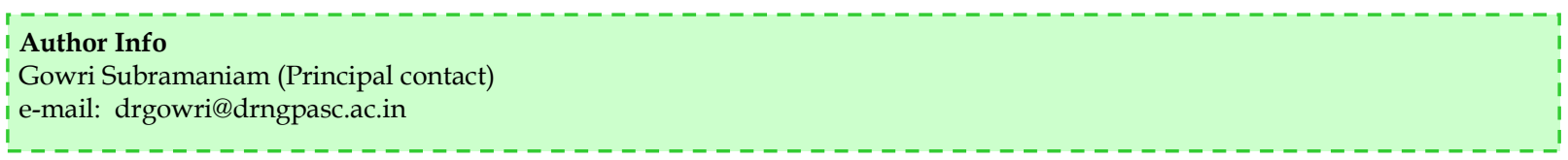

